\title{
Pengaruh return on assets, debt to equity ratio, dan firm size terhadap dividend
} payout ratio

\author{
Yudha Atmoko $^{1}$, F. Defung ${ }^{2}$, Irsan Tricahyadinata ${ }^{3}$ \\ Fakultas Ekonomi dan BisnisUniversitas Mulawarman, Samarinda. \\ ${ }^{1}$ Email: yudhaatmoke@gmail.com \\ ${ }^{2}$ Email: felisitas.defung@feb.unmul.ac.id \\ ${ }^{3}$ Email: irsan.tricahyadinata@feb.unmul.ac.id
}

\begin{abstract}
Abstrak
Tujuan penilitian ini yakni untuk menguji, mengetahui dan menjelaskan pengaruh Return On Assets, Debt to Equity Ratio, dan Firm Size terhadap Dividend Payout Ratio. Variabel bebas yang digunakan dalam penelitian ini adalah Return On Assets, Debt to Equity Ratio, dan Firm Size, sedangkan variabel terikat dalam penelitian ini yaitu Pembelian Dividend Payout Ratio. Populasi pada penelitian ini yakni Perusahaan Perbankan yang terdaftar di Bursa Efek Indonesia Periode 2011-2015.
\end{abstract}

Kata Kunci: Return on assets; debt to equity ratio; dividend payout ratio

\section{Effect of return on assets, debt to equity ratio, and firm size against dividend payout ratio}

\begin{abstract}
The purpose of this research is to test, know and explain the effect of Return On Assets, Debt to Equity Ratio, and Firm Size to Dividend Payout Ratio. The independent variables used in this research are Return On Assets, Debt to Equity Ratio, and Firm Size, while the dependent variable in this research is Purchase Dividend Payout Ratio. The population in this study is Banking Companies listed in Indonesia Stock Exchange Period 2011-2015.
\end{abstract}

Keywords: Return on assets; debt to equity ratio; dividend payout ratio 


\section{PENDAHULUAN}

Untuk mengurangi kemungkinan resiko dan ketidak pastian yang akan terjadi, investor memerlukan berbagai macam informasi, baik yang diperoleh dari kinerja perusahaan maupun informasi yang relevan seperti kondisi ekonomi dan politik dalam suatu Negara. Informasi yang diperoleh dari perusahaan lazimnya didasarkan pada kinerja perusahaan yang tercermin dalam laporan keuangan, investor dapat mengetahui kinerja perusahaan dalam kemampuannya untuk menghasilkan profitabilitas dan besarnya pendapatan dividen per lembar saham (dividen per share).

Kebijakan dividen cenderung menjadi salah satu elemen yang paling stabil dan dapat diprediksi oleh perusahaan, dan sebagian besar perusahaan mulai membayar dividen setelah mereka mencapai tahap kematangan bisnis dan ketika tidak ada lagi kesempatan investasi yang menguntungkan perusahaan (Al- Haddad et al., 2011). Proporsi dividen yang dibayarkan pada pemegang saham tergantung pada kemampuan perusahaan menghasilkan laba serta bentuk kebijakan dividen yang diterapkan oleh perusahaan yang bersangkutan. Prosentase dari laba yang akan dibayarkan kepada pemegang saham sebagai cash dividend disebut Dividend Payout Ratio (Andriyani, 2008).

Kebijakan dividen telah menjadi hal yang sangat diperhatikan oleh para manajer keuangan dan perusahaan pada umumnya. Perusahaan dihadapkan pada dilema, apakah akan membagikan dividen kepada pemegang saham, atau manahan laba untuk kegiatan investasi kembali dalam rangka pengembangan usaha (Okpara, 2010). Di sisi lainnya, pembagian dividen yang tinggi kurang disukai oleh manajemen karena akan mengurangi utilitas manajemen yang disebabkan oleh semakin kecilnya dana yang berada dalam lingkup kendali manajemen. Hal ini sesuai dengan residual theory of cash dividend (Karen, 2003) yang menyatakan bahwa kelebihan kas yang ada seharusnya dibagikan dalam bentuk dividen, akan tetapi manajemen tidak menyukai pembagian laba yang diperoleh dalam bentuk dividen. Manajemen lebih suka memperlakukannya sebagai laba ditahan, kecuali mengetahui bahwa dana tersebut tidak memberikan net present value (NVP) yang positif pada tambahan investasi.

\section{Kajiian Pustaka}

\section{Pengertian Dividen}

Dividen adalah proporsi laba yang dibagikan kepada pemegang saham perusahaan dalam jumlah yang sebanding dengan jumlah lembar yang dimilikinya (Baridwan, 2004). Dividen akan dibagikan kepada para pemegang saham, dimana hal ini menjadi faktor utama sebagai acuan direksi untuk menentukan besarnya dividen yang akan dibagikan.

Kebijakan dividen (dividend policy) adalah keputusan apakah laba yang diperoleh perusahaan akan dibagikan kepada pemegang saham sebagai dividen atau akan ditahan dalam bentuk laba ditahan guna pembiayaan investasi dimasa datang.

\section{Pengertian Dividend Payout Ratio}

Dividend Payout Ratio adalah rasio yang menunjukkan besarnya nilai dividen yang dibagikan oleh perusahaan kepada para investor. Keadaan yang dilematis sering dialami oleh perusahaan dalam melakukan kebijakan dividen itu sendiri, dimana di satu sisi investor menuntut untuk dibagikannya sejumlah dividen setelah kesepakatan dalam Rapat Umum Pemegang Saham (RUPS) agar memperoleh kepercayaan akankelangsungan prospek perusahaan dimasa mendatang, sedangkan disisi perusahaan menginginkan untuk menahan labanya sebagai langkah dalam melakukan pengembangan investasi guna untuk memperbesar perusahaannya..

\section{Return On Assets}

Return on assets adalah salah satu ukuran profitabilitas perusahaan dalam menghasilkan keuntungan dengan memanfaatkan aset yang digunakan untuk operasi. ROA merupakan rasio antara pendapatan bersih sesudah pajak terhadap total aset. ROA digunakan untuk melihat tingkat efisiensi operasi perusahaan secara keseluruhan. Posisi dari nilai ROA yang tinggi menunjukkan bahwa perusahaan berkemampuan dalam menghasilkan keuntungan yang berbanding dengan aset yang relatif tinggi. 


\section{Debt Equity Ratio}

Debt to Equity Ratio adalah rasio yang menunjukkan persentase penyediaan dana oleh pemegang saham terhadap pemberi pinjaman (Darsono, 2005). Semakin besar debt to equity ratio maka semakin besar modal pinjaman sehingga akan menyebabkan semakin besar pula beban hutang (biaya bunga) yang harus ditanggung perusahaan. Semakin besarnya beban hutang perusahaan maka jumlah laba yang dibagikan sebagai cash dividend akan berkurang.

\section{Firm Size}

Ukuran perusahaan adalah rata-rata total penjualan bersih untuk tahun yang bersangkutan sampai beberapa tahun. Dalam hal ini penjualan lebih besar daripada biaya variabel dan biaya tetap, maka akan diperoleh jumlah pendapatan sebelum pajak. Sebaliknya jika penjualan lebih kecil daripada biaya variabel dan biaya tetap maka perusahaan akan menderita kerugian (Brigham dan Houston 2001). Keadaan yang dikehendaki oleh perusahaan adalah perolehan laba bersih sesudah pajak karena bersifat menambah modal sendiri. Laba operasi ini dapat diperoleh jika jumlah penjualan lebih besar daripada jumlah biaya variabel dan biaya tetap.

\section{METODE}

Populasi dalam penelitian ini adalah perusahaan perbankan yang listing di Bursa Efek Indonesia (BEI) selama tahun 2011-2015. Teknik pengambilan sample dilakukan melalui metode purposive sampling dengan tujuan untuk mendapatkan sampel yang sesuai dengan tujuan penelitian. Metode purposive sampling merupakan metode pengambilan sampel yang didasarkan pada beberapa pertimbangan atau kriteria tertentu. Kriteria perusahaan yang akan menjadi sampel pada penelitian ini adalah sebagai berikut:

1. Perusahaan Perbankan yang terdaftar pada Bursa Efek Indonesia (BEI) secara berturut-turut dari tahun 2011-2015.

2. Perusahaan yang tidak membagikan dividen selama lima tahun berturut- turut pada tahun 2011-2015

3. Mempublikasikan laporan keuangan yang telah diaudit setiap tahun selama periode tahun 20112015.

Tabel 1. Kriteria Pemilihan Sampel

\begin{tabular}{clllc}
\hline No. & \multicolumn{3}{c}{ Keterangan } & Jumlah \\
\hline $\mathbf{1}$ & $\begin{array}{l}\text { Perusahaan Perbankan yang terdaftar pada } \\
\text { secara berturut-turut dari tahun 2011-2015. }\end{array}$ & $\mathbf{4 0}$ \\
$\mathbf{2}$ & $\begin{array}{l}\text { Perusahaan yang tidak membagikan dividen } \\
\text { turut pada tahun 2011-2015 }\end{array}$ & $\mathbf{1 0}$ \\
\hline & \multicolumn{3}{c}{$\begin{array}{l}\text { Perusahaan-perusahaan } \\
\text { berdasarkan variabel yang diteliti. }\end{array}$} & $\mathbf{3 0}$ \\
\hline \multicolumn{3}{c}{ Jumlah Perusahaan } \\
\hline
\end{tabular}

\section{Jenis dan Sumber Data}

Jenis data dan sumber data yang digunakan dalam penelitian ini merupakan data sekunder yang berupa laporan keuangan setiap perusahaan sampel dari tahun 2011-2015. Sumber yang digunakan adalah lapora keuangan perusahaan sampel yang terdapat pada Indonesian Stock Exchange (IDX).

\section{Metode Pengumpulan Data}

Teknik pengumpulan data untuk penelitian ini dilakukan dengan dokumentasi. Dokumentasi yang dilakukan adalah dengan mengumpulkan semua data sekunder yang terdaftar di Bursa Efek Indonesia periode 2011-2015. 


\section{Metode Analisis Data}

Analisis data dalam penelitian ini dilakukan dengan analisis regresi berganda untuk pengujian hipotesis. Analisis regresi berganda ini selain mengukur kekuatan hubungan antara dua variabel atau lebih, juga menunjukan arah hubungan antara variabel dependen dengan variabel variabel independen (Ghozali, 2006).

\section{Analisis Regresi Linear Berganda}

Model analisis yang dipakai dalam penelitian ini adalah regresi linear berganda. Analisis regresi berganda dilakukan untuk mengetahui hubungan variable independen (Return On Assets, Size, dan Debt to Equity Ratio) dengan variabel dependen (Kebijakan Dividen). Model analisis data dalam penelitian ini sebagai beriku Gujarati (2003):

$\mathrm{Y}=\mathrm{a}+\mathrm{b} 1 \mathrm{X} 1+\mathrm{b} 2 \mathrm{X} 2+\mathrm{b} 3 \mathrm{X} 3+\mathrm{e}$

Keterangan:

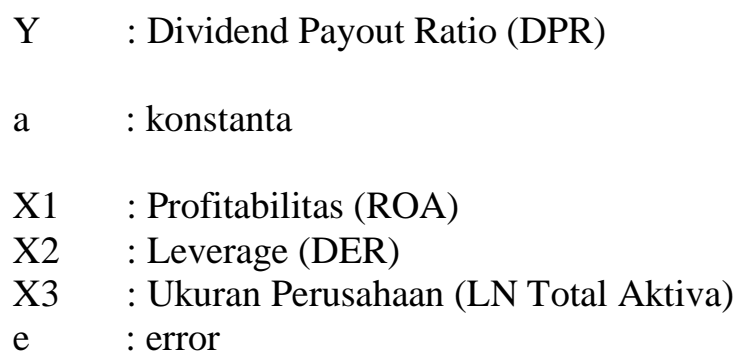

\section{HASIL DAN PEMBAHASAN}

\section{Uji t}

Uji t pada dasarnya menunjukkan seberapa jauh pengaruh satu variabel penjelas atau independen secara individual dalam menerangkan variasi variabel dependen. Pengambilan keputusan ini dilakukan berdasarkan perbandingan nilai signifikan dari nilai t hitung masing-masing koefisien regresi dengan tingkat signifikan yang telah ditetapkan, yaitu sebesar 5\% $(0,05)$.

\section{a. Pengaruh Variabel ROA terhadap DPR}

Variabel ROA memilki nilai P-Value $0,745>0,05$ dan nilai $\mathrm{t}$ hitung $0.326<1.659$ artinya bahwa variabel ROA tidak signifikan berpengaruh negative terhadap DPR, hal ini berarti Ho ditolak dan H1 diterima, hipotesis pertama menyimpulkan bahwa ROA mempunyai pengaruh Negatif 0.326, tidak signifikan terhadap Dividend Payout Ratio. Berdasarkan hasil perhitungan Uji t diperoleh koefisien (ROA) Sebesar -0.326 maka hipotesis X1 diajukan peneliti ditolak. Artinya ROA tidak mempunyai pengaruh yang signifikan dan negative terhadap Dividend Payout Ratio.

\section{b. Pengaruh Variabel DER terhadap DPR}

Variabel DER memilki nilai P-Value 0,000 < 0,05 dan nilai t hitung $9.469>1.659$ artinya bahwa variabel DER berpengaruh positive dan signifikan terhadap DPR, hal ini berarti Ho ditolak dan H1 diterima, hipotesis kedua menyimpulkan bahwa variabel DER signifikan berpengaruh positive terhadap Dividend Payout Ratio. Berdasarkan hasil perhitungan Uji t diperoleh koefisien (DER) Sebesar 9.469 maka hipotesis X2 diajukan peneliti diterima. Artinya DER mempunyai pengaruh signifikan dan positive terhadap Dividend Payout Ratio.

\section{c. Pengaruh Variabel Size terhadap DPR}

Variabel Size memilki nilai P-Value $0,000<0,05$ dan nilai t hitung $7.764>1.659$ artinya bahwa variabel Size signifikan berpengaruh positive terhadap DPR, hal ini berarti Ho ditolak dan H1 diterima, hipotesis ketiga menyimpulkan bahwa Size mempunyai pengaruh Positive 7.764, dan signifikan terhadap Dividend Payout Ratio. Berdasarkan hasil perhitungan Uji t diperoleh koefisien 
Size Sebesar 0.741 maka hipotesis X3 diajukan peneliti diterima. Artinya Size mempunyai pengaruh signifikan dan Positive terhadap Dividend Payout Ratio.

\section{Uji F}

Uji F pada dasarnya menunjukkan apakah semua variabel independen yang dimasukkan dalam model mempunyai pengaruh secara imultan terhadap variabel dependen.

Berdasarkan hasil uji ANOVA (Analysis of Varians) atau pengujian simultan (bersama - sama), menunjukkan bahwa nilai $\mathrm{F}$ hitung sebesar $170.128>\mathrm{F}$ tabel sebesar 2,69 dengan tingkat signifikasi kurang dari 0,05 yaitu sebesar 0,000. Maka Ho diterima, Jadi variabel Return on Asset, Debt Equity Ratio dan Firm Size mempunyai pengaruh signifikan secara simultan (bersama - sama) terhadap Dividend Payout Ratio.

\section{Koefisien Determinan}

Koefisien determinasi (R2) digunakan untuk mengukur seberapa jauh kemampuan model regresi dalam menerangkan variasi variabel dependen (Ghozali, 2011: 97). Adjusted R2 Koefisien determinasi (R2) mempunyai nilai berkisar antara $0<\mathrm{R} 2<1$. Nilai adjusted R2 yang kecil berarti kemampuan variabel-variabel independen dalam menjelaskan variasi variabel dependen sangat terbatas.

Hasil uji adjusted R2 pada penelitian ini diperoleh nilai Koefisien determinasi sebesar 0,823 yang berarti bahwa besarnya pengaruh variabel ROA, DER dan SIZE terhadap DPR sebesar 82.3\%, sedangkan sisanya sebesar $17.7 \%$ dipengaruhi oleh faktor lain yang tidak termasuk dalam penelitian ini.

\section{Pembahasan}

\section{1) Pengaruh Return on Asset Terhadap Dividend Payout Ratio}

Pada variabel ini menunjukkan bahwa apabila Return on Asset tidak signifikan terhadap variabel Dividend Payout Ratio, jika Return on Asset menurun maka Dividend Payout Ratio juga menurun. Hasil penelitian menunjukkan bahwa pengaruh negative variabel Return on Asset terhadap Dividend Payout Ratio menjelaskan bahwa penurunan profitabilitas perusahaan akan berdampak pada penurunan pembagian dividen yang akan dibayarkan.

Hasil penelitian ini bertolak belakan dengan hasil penelitian sebelumnya yang dilakukan oleh (Amidu dan Abor 2006), (Anil dan Kapoor 2008), dan (Puspita 2009). (Amidu dan Abor 2006) meneliti tentang faktor-faktor yang memengaruhi dividend payout ratio pada 22 perusahaan yang listed di Ghana Stock Exchange pada periode tahun 1998-2003. Hasil penelitiannya menunjukkan bahwa profitabilitas berpengaruh positif terhadap dividend payout ratio. (Anil dan Kapoor 2008) melakukan penelitian tentang faktor-faktor yang memengaruhi dividend payout ratio pada perusahaan-perusahaan IT di India.

\section{2) Pengaruh Debt Equity Ratio Terhadap Dividend Payout Ratio}

Hasil pengujian hipotesis menunjukkan bahwa debt to equity ratio berpengaruh positive terhadap Dividend Payout Ratio. Semakin rendah DER akan semakin tinggi kemampuan perusahaan untuk membayar seluruh kewajibannya. Hal ini disebabkan karena semakin rendah proporsi hutang yang digunakan untuk struktur modal suatu perusahaan, maka akan semakin rendah pula jumlah kewajibannya.

Hasil pengujian penelitian ini konsisten dengan hasil penelitian sebelumnya yang dilakukan oleh (Ismiyanti dan Hanafi 2004) yang meneliti tentang pengaruh kebijakan utang, kepemilikan manajerial, risiko dan kepemilikan institusional dengan variabel kontrol ROA dan IOS ((Investment Opportunity Set) yang diproksi dengan Book Value Equity/ Market Value Equity) terhadap dividend. Hasil penelitian tersebut menyimpulkan bahwa kebijakan hutang (diproksi dengan leverage) berpengaruh negatif terhadap kebijakan dividend. Hasil penelitian ini juga mendukung penelitian yang dilakukan oleh (Prihantoro 2003), (Andriyani 2008), dan (Appannan dan Sim 2011). (Prihantoro 2003) yang meneliti tentang estimasi pengaruh dividend payout ratio pada perusahaan publik di Indonesia menyatakan bahwa debt equity ratio mencerminkan kemampuan perusahaan dalam memenuhi seluruh kewajibannya. 


\section{3) Pengaruh Size Terhadap Dividend Payout Ratio}

Hasil analisis statistik untuk variabel Firm Size diketahui bahwa dapat disimpulkan bahwa Firm Size berpengaruh positif dan signifikan terhadap kebijakan dividen sehingga hipotesis ketiga diterima. Hasil penelitian ini konsisten sejalan dengan penelitian yang telah dilakukan oleh (Zaipul 2011) yang menyatakan bahwa semakin besarnya ukuran suatu perusahaan, maka kondisi tersebut memungkinkan pada semakin besarnya pembagian dividen. Hal ini menunjukkan bahwa dengan adanya kemudahan akses yang diperoleh ke pasar modal sebagai kemampuan yang fleksibel bagi perusahaan, menjadi faktor yang menguntungkan dalam hal kemampuan untuk mendapatkan dana dari pasar modal yang lebih besar. Alhasil, perusahaan mempunyai rasio pembayaran dividen yang cukup besar dimana dalam hal ini perusahaan yang sudah besar biasanya memiliki total aset yang besar pula.

Hal ini menunjukkan bahwa total assets yang dimiliki perusahaan digunakan sebagai jaminan untuk memperoleh pinjaman. Pinjaman tersebut digunakan kembali untuk menambah asset perusahaan, sehingga akan meningkatkan operasional dan penjualan perusahaan. Penjualan yang meningkat akan meningkatkan laba bersih yang mana dari laba bersih yang meningkat, perusahaan akan mengurangi saldo laba pada neraca untuk meningkatkan kemampuan rasio pembayaran dividen.

\section{SIMPULAN}

Berdasarkan hasil penelitian dan pembahasan pada bab IV, maka dapat diambil beberapa kesimpulan sebagai berikut:

1. Hasil analisis variabel secara inidividu menggunakan analisis regresi berganda didapatkan bahwa Return On Asset (ROA) berpengaruh negative dan tidak signifikan terhadap Dividen Payout Ratio (DPR) pada perusahaan perbankan yang terdaftar di Bursa Efek Indonesia periode 2011-2015. Sehingga dapat disimpulkan bahwa hipotesis pertama yang menyatakan bahwa ROA berpengaruh positif dan signifikan terhadap Dividen Payout Ratio (DPR) ditolak.

2. Hasil analisis variabel secara inidividu menggunakan analisis regresi berganda didapatkan bahwa Debt Equity Ratio (DER) berpengaruh positive dan signifikan terhadap Dividen Payout Ratio (DPR) pada perusahaan perbankan yang terdaftar di Bursa Efek Indonesia periode 2011-2015. Sehingga dapat disimpulkan bahwa hipotesis kedua yang menyatakan bahwa DER berpengaruh positif dan signifikan terhadap Dividen Payout Ratio (DPR) diterima.

3. Hasil analisis variabel secara inidividu menggunakan analisis regresi berganda didapatkan bahwa Firm Size berpengaruh positive dan signifikan terhadap Dividen Payout Ratio (DPR) pada perusahaan perbankan yang terdaftar di Bursa Efek Indonesia periode 2011-2015. Sehingga dapat disimpulkan bahwa hipotesis ketiga yang menyatakan bahwa SIZEpengaruh positif dan signifikan terhadap Dividen Payout Ratio (DPR) diterima.

\section{DAFTAR PUSTAKA}

Akbar, Muhammad Muzahid dan Noorjahan Parvez. 2009. "Impact of sevice, qualit, trust and customer satisfaction on customer loyalty. ABAC Vol. 29, No. 1, (January-April), pp.24-38.

Ariani, Dorothea Wahyu. 2003. Manajemen Kualitas: Pendekatan Sisi Kualitatif. Proyek Peningkatan Penelitian Pendidikan Tinggi Direktoran Jendral Pendidikan Tinggi. Depdiknas.

Daryanto, 2011, Sari Kuliah Manajemen Pemasaran, Bandung: PT Sarana Tutorial Nurani Sejahtera.

Dharmesta \& Handoko (2008). Manajemen Pemasaran Analisis Perilaku Konsumen. Yogyakarta: BPFE.

Garvin, David, "Managing Quality", di dalam Nasution, M.N. 2001. Manajemen Alutu Terpadu (Fotal Quality Management). Jakarta: Ghalia Indonesia.

Ghozali, Imam. 2006. Aplikasi Analisis Multi Variat dengan Program SPSS. Cetakan Keempat. Semarang: Universitas Dipenogoro.

Griffin, Jill, 2002. Customer Loyality And What It MattersNow More Thans Eve. www.Loyalitysolution.com. 
Griffin R. W. 2003. Management jilid 1. Jakarta: Erlangga.

Gujarati, Damodar. 2002. Ekonometrika Dasar, Erlangga, Jakarta.

Hatane Semuel, 2005. "Respons Lingkungan Berbelanja Sebagai Stimulus Pembelian Tidak Terencana pada Toko Serba Ada (Toserba) (Studi Kasus Carrefour Surabaya)". Jurnal Manajemen \& kewirausahaan, Vol.7. No.2. http://puslit.petra.ac.id/ puslit/journals/.

Hussein, Umar.(2002). Riset Pemasaran Perilaku Konsumen, Penerbit PT. Gramedia Pustaka Utama, Jakarta. 